Харківської державної академії культури ORCID 0000-0001-5421-1004

Кухаренко Анастасія Валеріївна, організатор фестивалю традиційної культури

«Пятровіца», м. Любань (Білорусь) ORCID 0000-0002-8578-5024

\title{
ЦІЛІ РИТУАЛЬНИХ ЦЕРЕМОНІЙ І ВИЗНАЧЕННЯ ХАРАКТЕРУ ДІЙ ЕПІЗОДІВ У СТРУКТУРІ ЦИКЛУ НАЦІОАЛЬНОЇ ВЕСІЛЬНОЇ ОБРЯДОВОСТІ
}

Мета роботи. Дослідження пов'язане зі встановленням мети ритуальних церемоній і визначенням характеру дій усіх епізодів, на які розкладено обряди, що входять до структури великого весільного циклу циклів. Методологія дослідження використовує структурно-функціональний метод. Створена структура дозволяє наочно продемонструвати, як змінюється характер дії від одного епізоду до іншого. Наукова новизна роботи полягає в дослідженні структури весільного обрядового циклу, який надає широку перспективу для отримання нових наукових результатів. Епізоди всіх без виключення обрядів базуються на обмежених за характером діях, котрі періодично повторюються. Єдиними неповторюваними є кульмінаційні епізоди, оскільки вони відображають ритуальні сакральні дії, пов'язані з метою проведення того чи іншого обряду. У трьох обрядах циклу саме в кульмінаціях здійснюється перехід головних персонажів до нових соціальних статусів. Висновки. Епізоди обрядів, які періодично повторюються, можна розподілити на сім груп. Неповторювані кульмінаційні епізоди зустрічаються в трьох перехідних обрядах, а в неперехідних кульмінацій нараховується 12, у двох прологах кульмінаційні епізоди взагалі відсутні. Така кількість вказує, що дослідження охопило всі 17 обрядів, які складають структуру ритуального циклу.

Ключові слова: родинні обряди; українське весілля; структурно-функціональний метод; епізоди обрядів; характер дій.

Кухаренко Александр Алексеевич, кандидат филологических наук, доцент, доцент кафедрьы телерепортерского мастерства Харьковской государственной академии культуры; Кухаренко Анастасия Валериевна, организатор фестиваля традиционной культуры «Пятровіца», г. Любань (Беларусь)

Цели ритуальных церемоний и определение характера действий эпизодов в структуре цикла национальной свадебной обрядности

Цель работы. Исследование связано с установлением цели ритуальных церемоний и определением характера действий всех эпизодов, на которые разложены обряды, входящие в структуру большого свадебного цикла циклов. Методология исследования использует структурно-функциональный метод. Созданная структура позволяет наглядно продемонстрировать, как изменяется характер действия от одного эпизода к другому. Научная новизна работы заключается в исследовании структуры свадебного обрядового цикла, который предоставляет широкую перспективу для получения новых научных результатов. Эпизоды всех без исключения обрядов базируются на ограниченных по характеру действиях, которые периодически повторяются. Единственными неповторяемыми являются кульминационные эпизоды, поскольку они отображают ритуальные сакральные действия, связанные с целью проведения того или другого обряда. В трех обрядах цикла именно в кульминациях осуществляется переход главных персонажей к новым социальным статусам. Выводы. Эпизоды обрядов, которые периодически повторяются, можно распределить на семь групп. Неповторяемые кульминационные эпизоды встречаются в трех переходных обрядах, а в непереходных кульминаций насчитывается 12, в двух прологах кульминационные эпизоды вообще отсутствует. Такое количество указывает, что исследование охватило все 17 обрядов, которые составляют структуру ритуального цикла.

Ключевые слова: семейные обряды; украинская свадьба; структурно-функциональный метод; эпизоды обрядов; характер действий.

Kukharenko Oleksandr, Candidate of Philological Sciences, Associate Professor, Associate Professor of the Department of TV Reporter Art of the Kharkiv State Academy of Culture; Kukharenko Anastasia, Organizer of the Fest of Traditional Culture Pyatrovitsa, Lyuban (Belarus)

Aims of ritual ceremonies and determining the nature of the actions of episodes in the structure of the cycle of national wedding ceremonies

(C) Кухаренко О. О., 2019

(C) Кухаренко А. В., 2019 
The purpose of the article. The research is connected with the establishment of the purpose of ritual ceremonies and determining nature of the actions of all episodes, to which ceremonies that are part of the structure of the large wedding cycle of cycles are dissociated. The methodology of research uses a structural and functional method. A created structure allows us to demonstrate clearly how the nature of action varies from one episode to another. The scientific novelty of the work is to study the structure of the wedding ceremonial cycle, which provides a broad perspective for obtaining new scientific results. Episodes of all rituals without exception are based on limited in character actions which are repeated from time to time. The only unrepeatable are culminating episodes since they reflect ritual sacred actions associated with the purpose of the ritual. The transition of the main characters to new social statuses is carried out in three rites of the cycle exactly in culmination. Conclusions. Episodes of rituals that are periodically repeated can be divided into seven groups. Unrepeatable culminating episodes occur in three transitional rites, and in non-transitive - there are 12 culminations, in two prologues there are no culminating episodes at all. Such amount indicates that the study covered all 17 rituals that make up the structure of the ritual cycle.

Key words: family rites; Ukrainian wedding; structural and functional method; episodes of ceremonies; the nature of the action.

Актуальність теми дослідження. Використання структурно-функціонального методу надає широку перспективу для отримання нових наукових результатів. Для дослідження українського весільного обряду за допомогою вказаного методу було створено структуру, в якій великий цикл циклів розкладається на три малих цикли - довесільний, весільний і післявесільний. Кожен 3 малих циклів включає певну кількість обрядів. У нашому випадку із 17-ти обрядів перші сім - пролог, сватання, заручини, оглядини, торочини, бгання короваю, гільце - утворюють довесільний цикл; наступні шість - пролог, вінчання, викуп, розплітання коси, приїзд молодої, комора - весільний цикл; останні чотири - пролог, приданки, перейма, перезва - малий післявесільний цикл обрядів. Усі названі обряди, в свою чергу, членуються на ще дрібніші складові - епізоди.

Аналіз досліджень і публікацій. До української весільної обрядовості у своїх дослідженнях зверталися В. Балушок, О. Боряк, І. Ігнатенко, Г. Кабакова, О. Кісь, С. Лащенко, М. Маєрчик. Структурні методи дослідження обрядовості використовували А. Байбурін, О. Гура, К. Леві-Строс, В. Пропп, В. Топоров. У попередніх публікаціях одного з авторів детально подано критерії, за якими обряди поділяються на епізоди та вибудовується структура весільного циклу для подальшого іiі дослідження [3, 82-87; 5, 5-18].

Мета дослідження - встановити цілі весільних обрядів і визначити, як змінюється характер дій від одного епізоду до іншого під час проведення традиційних ритуальних церемоній.

Виклад основного матеріалу дослідження. Епізоди всіх без виключення обрядів базуються на обмежених за характером діях, котрі періодично повторюються. Однак під час розгляду епізодів, доводиться стикатися не лише 3 повторенням подій, а також з їхнім розвитком, віддзеркаленням, подвоєнням ситуацій і т. і. У теорії драматургії відбувається подібний процес утворення різного типу дієвих конструкцій у рамках морфологічного закону, а саме повторення комплексів драматичних становищ [1, 170-228].

Не зважаючи на повторюваність переважної більшості епізодів, ті епізоди, що одночасно $є$ кульмінаціями обрядів, завжди залишаються унікальними й ексклюзивними. Навіть коли кульмінацією є епізод, який за характером дій можна віднести до приходів і повернень чи до створення обрядового атрибуту, в такому вигляді, як кульмінаційний елемент сюжету, він більше не зустрічається. Інша ситуація виникає 3 трьома кульмінаціями на початку довесільного циклу, які можна було б означити домовленостями. Але в пролозі домовленості відбуваються між окремими представниками двох таборів щодо можливості засилання сватів; під час сватання батьки й дівка дають згоду на заручини через сватів-посередників; а оглядини закріплюють уже безпосередні домовленості обох родин у повних складах щодо витрат на весілля та обсягів приданого за нареченою. Таким чином, усе це різні рівні домовленостей і неоднакова форма їх проведень; більш того, без попередньої домовленості наступна $\epsilon$ неможливою, як і сам процес проведення наступної ради без результату попередньої. Тому цілком можна стверджувати, що кульмінаційні епізоди в пролозі, сватанні й оглядинах дійсно є ексклюзивними й неповторними. Унікальність кульмінацій пов'язана з тим, що вони відображають суто ритуальні сакральні дії, до яких, окрім указаних, слід віднести випікання короваю, пришивання квітки до шапки нареченого; вінчання, викуп і прощання молодої, приїзд іiі до свого нового помешкання, представлення доказу цнотливості; повернення курки батькам з пирогами, спеченими жінкою, перегороджування дороги столом у обряді перейми та похід ряджених по селу під час перезви.

17 обрядів великого циклу українського весілля, за виключенням двох прологів малих циклів, мають кульмінаційні епізоди. У трьох перехідних обрядах у кульмінаціях відбувається зміна статусів 
головних учасників; інших кульмінацій, де такого переходу немає, нараховується 12. Прологи весільного та післявесільного циклів не мають кульмінаційних моментів; їхнє підгрунтя становлять ті самі повтори, що лежать в основі всіх інших епізодів [4, 36-49]. У кульмінаційних епізодах немає потреби визначати характер дії, оскільки їхні завдання повністю відповідають призначенню обрядів, складовими яких вони є. Така теза потребує доведення й слід встановити, що дійсно схожість дій у кульмінаціях за своїм характером обумовлена тими завданнями, які перед ними ставляться в рамках того чи іншого обряду весільного циклу. А оскільки й набір завдань у ритуалі має обмежений ресурс, то стає зрозумілим, чому епізоди обрядів нараховують всього біля півдесятка різних за характером дій. Приміром, головним завданням, що ставиться перед трьома вказаними обрядами - заручинами, вінчанням і коморою, є здійснення переходів від профанних статусів до сакральних на початку обрядового циклу, й від сакральних до профанних - у його кінці; обряд вінчання є проміжним $\mathrm{i}$ забезпечує перехід від сакральних статусів нареченого й нареченої до таких самих сакральних молодого й молодої. Завдання, що ставляться перед обрядом сватання, можна визначити як досягнення домовленостей між двома родинами, представлених батьками й головними дійовими особами - парубком і дівкою. Коли в обряді сватання домовленості будуть досягнуті, це відкриває шлях до подальших обрядових дій і для розгортання сакралізації; коли ні - відбувається згортання як обряду, так і сакралізації. Така можливість залишається до кульмінаційного моменту обряду заручин, а отже до переходу парубка й дівки до сакральних статусів нареченого й нареченої.

Оскільки пролог великого весільного циклу передує саме обряду сватання, цілком логічним є те, що його мета нічим не відрізняється від тієї, яка ставиться перед сватанням, - досягнення домовленостей між двома таборами [6, 53-56], з тією відмінністю, що домовленості прологу можна означити як попередні домовленості. Зрозуміло, що ніхто й ніколи не хотів отримати відмову під час сватання, тому парубок, а особливо його батьки, воліли попередньо домовитися про результат своїх подальших дій і визначитися, слід до них вдаватися чи ні. Можна навіть стверджувати, що потяг до здійснення будь-якої важливої справи тоді, коли існують домовленості в їі успішному результаті, в процесі історичного досвіду глибоко вкоренився в ментальність українця. І подія одруження, зокрема ритуал сватання, зіграли в цьому не останню роль.

Обряд оглядин для членів сім’ї нареченої, окрім здійснення традиційної потреби подивитися, оглянути, де й як у подальшому буде мешкати їхня донька, сестра чи племінниця, мав ще й суто практичну мету. А саме - визначити, чого не доставатиме молодятам у господарстві, а що може виявитися зайвим, і таким чином скорегувати речі й живність, що мають скласти придане молодої.

Торочини головним завданням ставлять перевірку й підготовку обрядових атрибутів рушників, хусток і т. i. У тому, що наречена для цієї процедури скликає до себе дружок, $\epsilon$ раціональне зерно: по-перше, це допомога, якої потребує наречена в такий відповідальний період свого життя; по-друге, сторонній погляд на підготовку до весілля мав дати свої корисні результати; по-третє, й найголовніше, наречена починає визначати власну команду двійників і першими в цій команді з'являються дру́жки.

Обряд бгання короваю також мав на меті вирішення суто практичного завдання виготовлення обрядового хліба, необхідного для проведення традиційних весільних дійств. Тут і надалі, аж до самого дня весілля, відбувається те, що болгарська дослідниця Р. Іванова називала створенням обрядових атрибутів [2, 156-163]. Такими атрибутами $є$ рушники, хустки, сорочка, коровай, шишки й верчі, а також вильце чи гільце - весільне дерево, котре створюється в процесі наступного обряду. Усі перераховані атрибути так чи інакше стосуються кульмінаційних епізодів у обрядах торочин і бгання; вони або присутні в кульмінації, або наближають іï, або є приводом для стягнення й залучення всіх учасників наступного обряду так, як це відбувається в обряді під назвою «гільце».

Не дивлячись на те, що обряд названо в честь весільного дерева, сам атрибут створюється на самому початку ритуальної дії. А кульмінацію складає пришивання дру́жкою квітки до шапки нареченого, оскільки квітка $є$ куди важливішим весільним символом, ніж дерево, бо її наявність на шапці свідчить про обраність цього персонажа та скору зміну ним соціального статусу нареченого на молодого, а далі й чоловіка. Якщо гільце символізує лише подію весілля, то квітка вказує на головного персонажа цієї події, статусний перехід якого $є$ головним завданням усього великого циклу циклів весільних обрядів.

Кульмінацією обряду викупу молодої є так звана «продаж» братами сестри, в результаті якої молодий «купує» собі дружину. Мета цієї досить умовної акції полягає в необхідності узаконити факт появи особи з чужого помешкання в родині молодого, яка 3 цього часу стає також і її родиною, а їхнє помешкання - ії помешканням. 
Але одним 3 найцікавіших 3 точки зору структури є обряд розплітання коси, оскільки тут проглядають віддзеркалення чи паралелі з іншим обрядом малого довесільного циклу. Молода під час покривання опиняється в ситуації, подібній до тієї, в якій знаходився наречений у обряді дівичвечора. Було вказано, що пришивання квітки до шапки нареченого свідчить про швидку зміну статусу й наголошує на обраності цього персонажа обрядової дії. Те ж саме можна сказати про стан молодої: ій розпускають косу, покривають волосся наміткою чи серпанком - означують, мітять, накладають знак іiі обраності та свідчення того, що найближчим часом молодій належить стати заміжньою дружиною. Обидва названі обряди містять у собі елемент ініціації й свідоцтво того, що учасники знаходяться напередодні значного й важливого кроку, де має трапитися все те, заради чого проводиться весь обрядовий цикл.

Комора безумовно $є$ кульмінаційним обрядом у великому весільному циклі, а кульмінаційним епізодом самого обряду - акт дефлорації й надання доказу цнотливості молодої жінки. Тут слід наголосити на одній суттєвій деталі: коли молода напередодні проведення обряду комори зізнається перед гостями й кається, що не зберегла «калину», їй це прощається. А у випадку, якщо вона вступила в обряд, але не змогла довести збереження цноти, вона й іiі батьки піддаються найжорстокішим насмішкам і знущанням. Можна було б припустити, що весільні гості є таким собі всепрощаючим громадським судом, здатним відпускати гріхи тим, хто щиро кається. Насправді, проблема в іншому: молода підлягає засудженню не за те, що вчасно не покаялася, а тому, що вступила в обряд і викликала відкриття джерела сакралізації з потойбіччя за допомогою брехні, бо в результаті виявляється, що не мала на це ніякого права.

Оскільки відкриття входу до потойбічного й вивільнення сакрального, як основи родючості, відбувалося не лише при здійсненні обрядів, а й під час зачаття дитини та в період сівби землеробських культур, тому неналежне ставлення до обрядової дії цілком могло якимось чином зашкодити сакралізації родючості в період запліднення, сіяння чи проростання. Належна побожність, із якою повинен виконуватися обряд, не могла навіть припустити, щоб під час сакральних дій використовувалися неправдиві свідчення; тому й виявлялася така прискіплива увага громади до, здавалося б, особистих, навіть інтимних питань окремих ії членів.

Післявесільний цикл містить три обряди, які мають кульмінаційний епізод. У приданках це поїздка чоловіка з побратимом (колишнім дружком) до батьків дружини; вони везуть пиріжки, спечені жінкою, та повертають назад чорну курку, задіяну в обряді приїзду молодої. Хоча обряд приданок продовжує ритуальні дії та доступ до потойбіччя вже закривається, сакральний центр ліквідовується й курка, що ототожнювала світ небіжчиків, більше не потрібна й ії повертають назад. Кульмінація перейми знаходиться саме в тому місці обряду, де односельці перегороджують столом шлях, яким молоде подружжя повертається з церкви. Цей обряд перекликається з викупом нареченої, але рівень сакралізації його значно нижчий, що пов'язано із запущеним механізмом десакралізації, завершенням циклу й згортанням дій.

Метою продовжити обрядову весільну дію хоч ненадовго, бажанням повернути найяскравіші миттєвості обряду можна пояснити присутність у перезві - останньому обряді циклу - перевдягання гостей-ряджених на циганів. А з іншого, залишки сакралізації, не дивлячись на перекриття їхнього джерела, продовжують свою дію в реальному світі, й дія ця не завжди буває благотворною, цілком можливо, що вона ще може чимось зашкодити. Тому гості воліють сховатися за масками циганів, прикинутися своїми - людьми з того світу, щоб уникнути шкідливого впливу потойбічних сил. Що ж стосується самого карнавального епізоду, то до цього моменту дія, як така, вже вичерпалася й закінчилася, господарі більше не хочуть накривати столи та пригощати присутніх; і тоді останні беруть ініціативу в свої руки, перевдягаються й самостійно забезпечують себе стравами та напоями. Усі три обряди останнього циклу пронизані відчуттям завершеності й це природньо, бо мета весілля досягнута й тепер необхідно достойно згорнути обрядову дію. Але цей процес відбувається не відразу а поступово; саме для поступового завершення обрядової дії існує післявесільний цикл обрядів і якраз вказаною функцією характеризується їхня головна мета.

Із зазначеного слід зробити висновок, що реалізація поставлених перед обрядом завдань відбувається не інакше, як у кульмінаційному епізоді. У структурі використовуються кульмінаційні події, які є унікальними й неповторними, інші епізоди за характером дій періодично повторюються.

Уже перші епізоди, що являють собою пролог до сакральної дії, дають нам зразок повторів, якими наповнене все дійство обрядового циклу. Перший і четвертий епізоди прологу містять основоположні перемовини, котрі ведуть до досягнення згоди й розкручування подальших ритуальних дій. У четвертому епізоді отримуємо повтор із дзеркальним відображенням подій першого епізоду, але в іншому часопросторі. Коли подальші дії, завдяки згоді сторін, стають 
можливими, вони надають достатньо прикладів повторення один одного: це може бути паралельне віддзеркалення подій у двох помешканнях одночасно, а може - зі зміщенням не лише простору, а й часу.

Зміна хронотопа є основним покажчиком близьких за змістом обрядових дій: перемовини відбуваються спочатку в помешканні парубка, потім - у дівки; в обох випадках - це перемовини 3 батьками. У обряді торочин віддзеркалення набуває ще й іншого значення: обряд проходить одночасно в різних місцях - наречений запрошує дружків, а в той самий час наречена запрошує дружок. Це є ознаками симультанної дії; те ж саме відбувається в подальшому: дружки збираються вдома в нареченого, дру́жки - в нареченої. Така ситуація дозволяє стверджувати, що дружки й дру́жки є двійниками нареченого й нареченої, тобто весільна дія охоплює двійникові втілення чоловічого й жіночого начал, що до певного моменту протиставляються одне одному.

Віддзеркалення не завжди вимагає часової єдності, тому до даної функції слід віднести обряди, котрі $є$ відображенням одного з іншим, хоча й належать до різних обрядів: на сватання й заручини посланці парубка йдуть до дівки, а на оглядини родичі нареченої відправляються до нареченого; понеділок після весілля гості проводять переважно в помешканні чоловіка, а вівторок, який пов'язаний з обрядом перезви, - в батьків дружини.

Оскільки парубок кілька разів протягом кількох днів навідує дівку, такий прихід слід розглядати як грань внутрішнього циклу, яка являє собою поліетапну обрядову дію. При цьому прихід парубка $є$ константою, на відміну від мобільних дій, які можливо змінювати та варіювати в часі й просторі. Вперше для виконання обряду парубок приходить до дівки перед заручинами, вдруге - на торочини, втретє - під час обряду дівич-вечора, вчетверте - перед вінчанням і вп'яте - щоб викупити та забрати молоду. Те, що кожен наступний прихід являє собою одну й ту саму дію, але на якісно вищому рівні, доводить факт набуття персонажем нового статусу: вперше він приходить парубком у якого немає жодного підтвердження прав на дівку, вдруге - вже як наречений, котрий отримав хустку, що свідчить про певні домовленості й права - він уже ночував у нареченої; втретє приходить 3 дружками, котрі, як зазначалося, являють собою двійників нареченого й уособлюють чоловіче начало, а дружка пришиває йому до шапки квітку, що також підтверджує його статус $\mathrm{i}$ право. Отже функції від одного приходу до іншого розширюються. Остаточний п'ятий прихід здійснюється вже в статусі молодого, що свідчить про одержання повного права на молоду, оскільки всі необхідні процедури дотримані, тому залишається лише викупити й забрати іiі з собою. Протягом проведення обрядового циклу парубок навідує дівку в різних статусах п’ять разів, але ці відвідини є тимчасові, оскільки він завжди повертається додому. Натомість молода приходить до помешкання молодого лише один раз, перед обрядом комори, але не для того, щоб перебувати там тимчасово, а щоб залишитися назавжди. Це та принципова різниця, що розділяє представників антиномій обрядового циклу - чоловічого й жіночого начал.

Указуючи на очевидні повтори, мається на увазі, що всі епізоди обрядів великого циклу циклів можна розподілити за характером дій на кілька груп; у нашому випадку їх нараховується сім: 1) домовленості, 2) запросини, 3) приходи й повернення, 4) гостини й гуляння, 5) пошанування сакральних дій, стихій і предметів, 6) створення обрядового атрибуту, 7) благословення й обдаровування. Восьмою групою, чи двома - восьмою й дев'ятою групами є два види кульмінацій, уже докладно розглянуті. При групуванні за характером дії 382 епізодів і 8 різновидів розкладаються всі без виключення епізоди. Це підтверджує, що зроблений розподіл є вірним, а створена структура дійсно відображає ті дії та функції, що здійснюються учасниками обрядів і відображаються складовими елементами структури.

Висновки. У створеній структурі циклу весільних обрядів епізоди, що базуються на обмежених за характером діях і періодично повторюються, розподіляються на сім груп. Єдиними неповторюваними є кульмінаційні епізоди кількістю 3+12 (у перехідних і неперехідних обрядах); усі вони відображають ритуальні сакральні дії й пов'язані з метою проведення того чи іншого обряду. У двох прологах малих циклів кульмінація відсутня: їхнє підгрунтя становлять ті самі повтори, що лежать в основі всіх інших епізодів. Загальна кількість кульмінаційних епізодів і їхня відсутність вказує на те, що дослідження охопило всі 17 обрядів, які складають структуру ритуального циклу.

\section{Jimepamypa}

1. Волькенштейн В. М. Драматургия. Метод исследования драматических произведений / 2 изд., доп. М. : Федерация, 1929. 273 с.

2. Иванова Р. Българската фолклорна сватба. София : Българската АН, 1984. 264 с.

3. Кухаренко О. О. Дослідження національної обрядовості за допомогою структури весільного циклу // Українська культура: минуле, сучасне, шляхи розвитку. Рівне : РДГУ, 2016. Вип. 23. С. 82-87. 
4. Кухаренко О. О. Критерії поділу структури весільних обрядів // Парадигма пізнання: гуманітарні питання. Київ, 2016. № 8. С. 36-49.

5. Кухаренко О. О. Побудова структури української весільної обрядовості // Парадигма пізнання: гуманітарні питання. Київ, 2016. № 7. С. 5-18.

6. Труды этнографическо-статистической экспедиции в Западно-Русский край / coбр. П. П. Чубинским. Т. 4. СПб., 1877. XXX, 715 с.

\title{
References
}

1. Volkenshtein, V. M. (1929). Dramaturgy. Method for the study of dramatic works. Moskow: Federatsiia [in Russian].

2. Ivanova R. (1984). Bulgarian folklore wedding. Sofia: Blgarskata AN [in Bulgarian].

3. Kukharenko, O. O. (2016). Investigation of national ritualism with the help of the structure of the wedding cycle. Ukrainska kultura: mynule, suchasne, shliakhy rozvytku, 23, 82-87 [in Ukrainian].

4. Kukharenko, O. O. (2016). Criteria for the division of the structure of wedding ceremonies. Paradygma piznannia: gumanitarni pytannia, 8, 36-49 [in Ukrainian].

5. Kukharenko, O. O. (2016). Construction of the structure of Ukrainian wedding ceremonies. Paradygma piznannia: gumanitarni pytannia, 7, 5-18 [in Ukrainian].

6. Chubinskii, P. P. (1877). Proceedings of the ethnographic-statistical expedition to the Western Russian region, 4. Sankt-Peterburg [in Russian].

Стаття надійшла до редакиії 17.12.2018 p.

УДК 316.7 [ 316.347 (= 161.2): 130.1

\author{
Сапожнік Ольга Василівна, \\ кандидат педагогічних наук, доцент, \\ докторант Національної академії керівних \\ кадрів культури і мистецтв \\ ORCID 0000-0003-3510-5817 \\ olgavasylivna08@gmail.com
}

\section{КУЛЬТУРОЛОГІЧНИЙ ЗМІСТ ПОНЯТТЯ ІДЕНТИЧНОСТІ}

Метою дослідження $\epsilon$ окреслення культурологічного змісту поняття ідентичності, розкриття співвідношення культурної, релігійної та мистецької складової ідентифікаційних процесів. У дослідженні висвітлена роль духовної культури, в тому числі релігійного мистецтва у становленні самосвідомості та самоутвердженні нації у цивілізаційному поступі України. Означено духовний вплив православ'я як релігійного стрижня у формуванні національних контентів культурної ідентичності. Методологія дослідження проявилась у застосуванні культурологічного підходу до поняття ідентичності, діалектичних методів аналізу, синтезу, зіставлення, порівняння, що дало можливість виокремити спектр проблематики. Наукова новизна полягає в тому, що уточнюється культурологічний зміст поняття ідентичності в контексті ії світоглядних, релігійних, естетичних вимірів. Поглиблюється розуміння духовного впливу українського православ'я на становлення національних контентів культурної ідентичності. Висновки. Обгрунтовано, що створення української державно-політичної ідентичності, орієнтованої на спільне майбутнє існування, при збереженні й розвитку етнічних, культурних та релігійних ідентичностей, спроможне значно сприяти зміцненню соціальної єдності країни, суспільства, істотно посилити державу. Означено, що консолідуючим фактором тут виступають культура і релігія в їх намаганні до вироблення спільної системи цінностей, яка повинна базуватися на визнанні пріоритету поваги до кожної людини, кожної етноконфесійної спільноти та збереження релігійної толерантності, що забезпечить остаточне утвердження культурно-національної ідентичності.

Ключові слова: духовна культура, ідентичність, культурна ідентичність, нація, національно-релігійна ідентифікація, православна Церква.

Сапожник Ольга Васильевна, кандидат педагогических наук, доцент, докторант Национальной академии руководящих кадров культуры и искусств

Культурологическое содержание понятия идентичности

Целью исследования является определение культурологического содержания понятия идентичности, раскрытие сооотношения культурных, религиозных и художественных составляющих процесса идентификации. В исследовании означивается роль духовной культуры, включая религиозное искусство в формировании идентичности и самоутверждении нации в цивилизационном прогрессе Украины. Отмечено духовное влияние православия как религиозного стержня в формировании национального контента культурной

(C) Сапожнік О. В., 2019 